\title{
Amyloid-beta modulates microglial responses by binding to the triggering receptor expressed on myeloid cells 2 (TREM2)
}

$\mathrm{Li}_{\text {Zhong }}{ }^{1 \dagger}$, Zongqi Wang ${ }^{1+}$, Daxin Wang ${ }^{1 \dagger}$, Zhe Wang ${ }^{1 \dagger}$, Yuka A. Martens ${ }^{2+}$, Linbei Wu${ }^{1}$, Ying Xu' ${ }^{1}$, Kai Wang ${ }^{1}$, Jianguo Li ${ }^{1}$, Ruizhi Huang ${ }^{1}$, Dan Can ${ }^{1}$, Huaxi $\mathrm{Xu}^{1,3}$, Guojun Bu ${ }^{1,2^{*}}$ and Xiao-Fen Chen ${ }^{1,4^{*}}$ (D)

\begin{abstract}
Background: TREM2 is an innate immune receptor specifically expressed in microglia. Coding variations in TREM2 have been reported to increase the risk for Alzheimer's disease (AD) and other neurodegenerative diseases. While multiple studies support a role for TREM2 in microglial recruitment to amyloid plaques, the chemoattractant factor modulating TREM2-dependent microglial responses has not been defined.
\end{abstract}

Methods: Potential binding of oligomeric amyloid- $\beta$ 1-42 (oA $\left.\beta_{1-42}\right)$ to TREM2 was tested by complementary approaches including solid phase binding, surface plasmon resonance and immunoprecipitation assays. The ability of oA $\beta_{1-42}$ to activate TREM2 signaling pathways was examined by analyzing the phosphorylation of Syk and Akt in primary microglia as well as TREM2-mediated signaling in a reporter cell system. Lastly, the functional outcome of oA $\beta_{1-42}$ TREM2 interaction was tested by examining impacts on microglial migration in vitro and clustering around oA $\beta_{1-42^{-}}$ bearing brain areas in vivo.

Results: We found that $O A \beta_{1-42}$ bound to TREM2 with high affinity and activated TREM2-dependent signaling pathway. Neither monomeric nor scrambled A $\beta$ bound to TREM2 supporting a specific interaction between oA $\beta$ and TREM2. The disease-associated mutations of TREM2 reduced its binding affinity to oA $\beta_{1-42}$. Furthermore, we identified several positively charged amino acids within residues 31-91 of TREM2 that were crucial for its interaction with oA $\beta_{1-42}$. Importantly, oA $\beta_{1-42}$ promoted microglial migration in vitro and clustering in vivo in a TREM2-dependent manner.

Conclusions: Our data establish a critical link between oA $\beta_{1-42}$, a major pathological component of $A D$, and TREM2, a strong genetic risk factor for AD expressed in microglia, and suggest that such interaction contributes to the pathogenic events in $A D$ by modulating microglial responses.

Keywords: $\beta$-amyloid, microglia, migration, TREM2, Alzheimer's disease

\footnotetext{
* Correspondence: bu.guojun@mayo.edu; chenxf@xmu.edu.cn

${ }^{\dagger}$ Equal contributors

${ }^{1}$ Fujian Provincial Key Laboratory of Neurodegenerative Disease and Aging

Research, Institute of Neuroscience, Medical College, Xiamen University,

Xiamen 361102, China

Full list of author information is available at the end of the article
} 


\section{Background}

Alzheimer's disease (AD) is the most common form of dementia with histopathological hallmarks of amyloid- $\beta$ $(\mathrm{A} \beta)$ plaques and tau neurofibrillary tangles in the brain $[1,2]$. While the mechanism by which neurodegeneration occurs in AD is not entirely clear, disturbed $A \beta$ clearance and plaque removal by microglia likely contribute to $A \beta$ accumulation and neuritic dystrophy $[3,4]$. As the brain resident innate immune cells, microglia constantly survey the microenvironment and become activated in response to pathogenic components that disrupt the homeostasis of the nervous system [5]. Intriguingly, microglia have been identified to constitute a protective barrier that prevents the outward extension of amyloid fibrils [6, 7]. The involvement of microglia in $\mathrm{AD}$ is further supported by recent genome-wide association and genome sequencing studies showing that rare coding variants in genes highly expressed in microglia as risk factors for late-onset $A D$ [8-15]. Single-cell RNA-sequencing in AD mouse model has also identified a novel microglia type that is associated with $\mathrm{AD}$ and restricts its development [16]. Therefore, mounting evidence supports a causal role of microglial dysfunction in AD.

TREM2 is a cell surface receptor of the Ig superfamily that is specifically expressed by microglia within the central nervous system (CNS) [17]. Interest in TREM2 stems from its genetic mutations associated with several neurodegenerative disorders [18]. Homozygous missense mutations of TREM2 including Y38C or T66 M have been identified to be associated with Nasu-Hakola disease (NHD) [19]. The R47H mutation in TREM2 constitutes one of the strongest single allele genetic risk factors for $\mathrm{AD}$, with an odds ratio similar to that of carrying an apolipoprotein E $(A P O E) \varepsilon 4$ allele $[8,9,19]$. The R62H, D87N and T96 $\mathrm{K}$ mutations in TREM2 were also linked to AD after extensive analyses of TREM2 polymorphisms [8, 10, 20]. However, the precise effects of TREM2 mutations on AD pathogenesis remain elusive.

TREM2 consists of an ectodomain, a transmembrane region and a short cytoplasmic tail. By coupling with DNAX-activating protein of $12 \mathrm{kDa}$ (DAP12), TREM2 regulates a wide array of functions in microglia including cell survival, proliferation, phagocytosis, and inflammation [21-24]. Recent studies in Trem2-deficient AD mouse models have showed contradictory results regarding the amounts of $A \beta$ plaques accumulation $[21,25,26]$. A later study indicated that Trem 2 deficiency has opposing effects on amyloid pathology at early and late stages of $\mathrm{AD}$ progression [27]. Nevertheless, it has been consistently reported that Trem 2 deficiency leads to reduced number of microglia around amyloid plaques, allowing greater amount of plaque pathology and related toxicity [26, 28]. However, it remains unknown how TREM2 affects the recruitment of microglia to the vicinity of plaque.
A diverse set of potential TREM2 ligands that are anionic or lipidic in nature have been proposed [29]. Bacteria and poly-anionic molecules were the first ligands proposed for TREM2 [30, 31]. TREM2 was also found to bind macrophages [32], astrocytes [33] and neurons [34]. Recently, TREM2 was shown to bind phospholipids [21], apolipoproteins (including apoE, apoJ and apoA) and lipoprotein particles (including low-density lipoprotein or "LDL") [35-37]. The binding of apolipoproteins to TREM2 was shown to facilitate either the phagocytosis of apoptotic neurons or the uptake of $\mathrm{A} \beta$ by microglia [35, 37]. Interestingly, the $A D$ risk-associated variants, including $\mathrm{R} 47 \mathrm{H}, \mathrm{R} 62 \mathrm{H}$ and $\mathrm{D} 87 \mathrm{~N}$, have reduced affinity to these ligands. While multiple TREM2 ligands have been proposed, the identification of bona fide endogenous TREM2 ligands and the exploration of their physiological and pathological roles remain elusive. In this study, we found that oA $\beta_{1-42}$, but not monomeric or scrambled $A \beta$, bound to TREM2 with high affinity. The disease-associated mutations of TREM2 reduced its binding affinity to oA $\beta_{1-42}$. We further identified the specific region of TREM2 encompassing the arginine 47 and 62 residues that is critical for binding to oA $\beta_{1-42}$. Functional analyses revealed that $\mathrm{oA} \beta_{1-42}$ activated TREM2 signaling pathway, promoted microglial migration and clustering in oA $\beta_{1-42^{-}}$ bearing brain regions via a TREM2-dependent manner. Our data provide mechanistic insight by which microglia recognize $A \beta$-related pathologies in $A D$.

\section{Methods}

\section{Reagents and antibodies}

Granulocyte-macrophage colony-stimulating factor (GM-CSF, 415-ML-010), RAGE-Fc recombinant protein (1145-RG-050) and anti-Fc antibody (MAB110) were purchased from R\&D systems. Anti-Phospho-Syk (Tyr525/ 526) (2711 s), anti-total-Syk (13,198 s), anti-Phospho-Akt (Ser473) (4060 s), anti-total-Akt (4685 s) and anti- $\beta$-actin antibody (4970 s) were purchased from Cell Signaling Technology. Anti-A $\beta$ antibody (MOAB-2, ab126649) was from Abcam. Unlabeled $A \beta_{1-42}$ (AS-20276), FAM-labeled $\mathrm{A} \beta_{1-42}$ (AS-23525-05) and scrambled $A \beta_{42}$ (AS-25382) were from AnaSpec. The $\mathrm{mA} \beta_{1-42}$ and oA $\beta_{1-42}$ were prepared as previously described with minor modification $[38,39]$. Dissolved peptides in DMSO $(5 \mathrm{mM})$ were diluted to $100 \mu \mathrm{M}$ with cold phenol-free F-12 cell culture media (Gibco) and sonicated for $10 \mathrm{~min}$ to make $\mathrm{mA} \beta_{1-42}$ which was used freshly. Part of the peptides were then incubated at $22{ }^{\circ} \mathrm{C}$ for $16 \mathrm{~h}$ followed by $24 \mathrm{~h}$ incubation at $4{ }^{\circ} \mathrm{C}$, centrifuged at $16,000 \times \mathrm{g}$ for $15 \mathrm{~min}$, and the collected supernatant was used as oA $\beta_{1-42}$.

\section{Western blotting}

Cells were lysed with NP-40 lysis buffer (1\% NP-40, $50 \mathrm{mM}$ Tris- $\mathrm{HCl}, \mathrm{pH}$ 8.0, $150 \mathrm{mM}$ sodium chloride 
containing protease inhibitor mixture from Roche Applied Science) $24 \mathrm{~h}$ post transfection. Protein concentrations were determined using the BCA protein assay kit (Thermo Fisher Scientific, 23,225). Equal amounts of samples were subjected to sodium dodecyl sulfatepolyacrylamide gel electrophoresis (SDS-PAGE). Proteins were transferred onto PVDF membranes and probed with specific antibodies. Detection was performed using corresponding secondary antibodies and immunoreactive bands were quantified using ImageJ.

\section{Immunoprecipitation assay}

Two micrograms of oA $\beta_{1-42}$ were added into $400 \mu \mathrm{L}$ of $1 \%$ solution of Tween-20 in TBS (1\% TBST) with protease inhibitor cocktail. Two micrograms of sTREM2-Fc, sTREM1-Fc or Fc protein was pre-bound to $25 \mu \mathrm{L}$ of protein A beads (Thermo Fisher Scientific, 20,334). The beads were then incubated with oA $\beta_{1-42}$ in $1 \%$ TBST at $4{ }^{\circ} \mathrm{C}$ overnight. Beads were washed 5 times with $1 \%$ TBST for $3 \mathrm{~min}$, resuspended in $20 \mu \mathrm{L} 2 \times$ SDS loading buffer and subjected to electrophoresis on $4-12 \%$ Bis-Tris NuPAGE precast gels (Thermo Fisher Scientific, NP0322PK2).

\section{Immunofluorescence staining}

Human embryonic kidney $293 \mathrm{~T}$ cells (HEK $293 \mathrm{~T}$ ) were transfected with pmCherry-N1, pmCherry-TREM1 or pmCherry-TREM2 plasmid. Twenty-four hours after transfection, cells were washed 3 times with DMEM and incubated with $1.0 \mu \mathrm{M}$ FAM-labeled $\mathrm{oA} \beta_{1-42}$ for $2 \mathrm{~h}$ at $4^{\circ}$ C. After 3 washes with PBS, cells were fixed with $4 \%$ paraformaldehyde for $15 \mathrm{~min}$. Cells were then stained with DAPI for $3 \mathrm{~min}$ and then washed twice with PBS for $15 \mathrm{~min}$. Coverslips were mounted on the glass slide using antifade reagent (Thermo Fisher Scientific, P36935) and observed using NIKON A1R Plus confocal microscope.

\section{Expression and purification of sTREM2-Fc fusion proteins}

The human TREM2 extracellular domain tagged with Fc that carries different fragments and mutations were cloned and purified from the conditioned medium of HEK 293 T cells as previously described [35]. Purified proteins were quantified with the $\mathrm{BCA}$ protein assay kit and the purity was determined on silver-stained SDS-PAGE gels.

\section{Solid phase binding assay}

A 96-well plate (Corning Incorporated) was coated with $100 \mathrm{nM} \mathrm{oA} \beta_{1-42}$ in PBS overnight at $4{ }^{\circ} \mathrm{C}$. Wells were washed with $0.05 \%$ PBST and blocked with $4 \%$ BSA for $1 \mathrm{~h}$ at $37^{\circ} \mathrm{C}$. Purified Fc or sTREM2-Fc proteins diluted in PBST containing 0.5\% BSA were added and incubated for $30 \mathrm{~min}$ at $37^{\circ} \mathrm{C}$. After washing, the bound proteins were detected with biotinylated-anti-Fc antibody for $1 \mathrm{~h}$ at $37{ }^{\circ} \mathrm{C}$. Plates were washed and then incubated with avidin-HRP for $30 \mathrm{~min}$ at $37{ }^{\circ} \mathrm{C}$, washed again, and developed with TMB substrate solution (Sigma Aldrich, T5569), and read at $620 \mathrm{~nm}$.

\section{Mouse primary microglial culture}

All animal experiments were conducted in compliance with the protocols of the Institutional Animal Care and Use Committee at Xiamen University. Trem2-knockout mice (KO, on $\mathrm{C} 57 \mathrm{BL} / 6 \mathrm{~N}$ background) and wild-type (WT) C57BL/6 N mice were obtained from the UC Davis Knockout Mouse Project (KOMP) repository as described previously [35]. Primary microglial cultures were prepared as previously described $[35,40]$. WT or Trem2-KO mice at postnatal day 1-3 were used to prepare mixed glial cultures. Cells were plated onto polylysine coated flasks and grown in fresh DMEM (Gibco) supplemented with 10\% FBS (Gibco). Medium was changed after 3 days to that contains $25 \mathrm{ng} / \mathrm{mL}$ GM-CSF and 10\% FBS. Primary microglial cells were harvested after 10-12 days in culture and once every 3 days thereafter (up to two harvests).

\section{Transwell assay}

Cell migration assay was performed with Transwell cell culture inserts comprised of two chambers separated by an $8.0 \mu \mathrm{m}$ polycarbonate membrane (Costar, 3422). Primary microglial cells $\left(5 \times 10^{4}\right)$ suspended in serumfree DMEM were added to the upper chamber of the inserts with serum-free DMEM in the bottom chamber. After $30 \mathrm{~min}$ incubation at $37{ }^{\circ} \mathrm{C}$, the bottom medium was replaced with DMEM containing vehicle, $0.5 \mu \mathrm{M}$ $\mathrm{oA} \beta_{1-42}$ or $10 \% \mathrm{FBS}$. After $20 \mathrm{~h}$, cells remained on the upper surface of the membrane were removed by scraping with a cotton swab. Cells that migrated through the membrane were fixed with $4 \%$ paraformaldehyde, stained with hematoxylin and eosin, and counted under Nikon inverted microscope.

\section{TREM2 reporter assay}

BWZ thymoma reporter cells (WT and TD4) were a generous gift from Dr. William E. Seaman (UCSF). BWZ cells express lac $Z$ under control of the promoter for nuclear factor of activated T cells (NFAT) [41]. The TD4 cells are stably transfected to co-express TREM2 and DAP12 [34]. TD4 or WT cells were seeded in 96-well plates at $10^{5}$ cells/well in RPMI media supplemented with $10 \mathrm{ng} / \mathrm{mL}$ phorbol 12-myristate 13-acetate (PMA). Ionomycin was added to a final concentration of $1 \mu \mathrm{M}$ to serve as a positive control. Reporter cells were stimulated with different concentrations of oA $\beta_{1-42}, \mathrm{~mA} \beta_{1-42}$ or $\operatorname{scA} \beta_{42}$ for $16 \mathrm{~h}$ at $37^{\circ} \mathrm{C}$, washed once with $\mathrm{PBS}$, and 
lysed in a buffer containing $100 \mathrm{mM}$ 2-mercaptoethanol, $9 \mathrm{mM} \mathrm{MgCl} 2,0.125 \% \mathrm{NP}-40$, and $0.3 \mathrm{mM}$ chlorophenol red- $\beta$-D-galactopyranoside. After $4 \mathrm{~h}$ at $37{ }^{\circ} \mathrm{C}$, absorbance was measured at $595 \mathrm{~nm}$, with correction for background absorbance at $630 \mathrm{~nm}$.

\section{Surface Plasmon Resonance assay}

Surface Plasmon Resonance (SPR) analysis was performed at $25^{\circ} \mathrm{C}$ using the Biacore T200 (GE Healthcare). Purified sTREM2-Fc and Fc protein were immobilized onto Biacore CM5 (GE Healthcare, BR-1005-30) chip using amine coupling kit (GE Healthcare, BR-1000-50). oA $\beta_{1-42}$, $\mathrm{mA} \beta_{1-42}$ or scA $\beta_{42}$ was tested with a gradient concentration of $1.25 \mu \mathrm{M}, 2.5 \mu \mathrm{M}, 5.0 \mu \mathrm{M}$ and $10.0 \mu \mathrm{M}$ respectively.

\section{Stereotactic injection of $\mathrm{oA} \boldsymbol{\beta}_{1-42}$}

WT or Trem2-KO male mice at 6 months of age were anesthetized and placed in a stereotaxic frame. Investigators were blind to the condition of each animal during the experimental procedure and the quantification and analysis stages. A skin incision was made and holes were drilled at defined $\mathrm{x}( \pm 2.0 \mathrm{~mm}$ from bregma $)$ and y $(-2.2 \mathrm{~mm}$ from bregma) positions. The left and the right hemisphere were injected with FAM-oA $\beta_{1-42}$ (a total of $1.5 \mu \mathrm{g}$ in $3.0 \mu \mathrm{L}$ ) or vehicle at $0.30 \mu \mathrm{L} / \mathrm{min}$ with z-depths of $2.0 \mathrm{~mm}$, respectively. Before being withdrawn slowly, the syringe was left in place for $10 \mathrm{~min}$ after each injection. Four or sixteen hours after injection, mice were anesthetized and perfused with ice-cold PBS. Brains were fixed in $4 \%$ PFA overnight at $4{ }^{\circ} \mathrm{C}$, transferred to $30 \%$ sucrose for $48 \mathrm{~h}$ before embedded for cryostat sectioning.

\section{Immunohistochemistry and microscopy}

Twelve- $\mu \mathrm{m}$ thick cryosections were washed in PBS for $15 \mathrm{~min}$, permeabilized in 5\% normal donkey serum and $0.2 \%$ Triton $\mathrm{X}-100$ for $1 \mathrm{~h}$, followed by $48 \mathrm{~h}$ ' incubation with Ibal antibodies at $4{ }^{\circ} \mathrm{C}$. The cryosections were washed with PBS for $30 \mathrm{~min}$ and treated with the Alexa-fluorophore-conjugated secondary antibodies for $2 \mathrm{~h}$ at RT. Sections were stained with DAPI $(5 \mu \mathrm{g} / \mathrm{mL})$, washed and mounted with anti-fade reagent. For confocal microscopy, $6 \mu \mathrm{m}$ z-stacks (consisting of 13 optical slices of $0.5 \mu \mathrm{m}$ thickness) were acquired using a NIKON A1R Plus confocal microscope.

\section{Statistics}

Data were obtained from at least three independent experiments, and presented as mean \pm standard deviation (SD). Statistical analyses were performed using Graphpad Prism 5.0 software or SPSS software. Statistical significance was determined by one-way ANOVA or two-way ANOVA when more than two groups were compared and unpaired Student's $t$-test for single comparisons. $p<0.05$ was considered significant.

\section{Results \\ Oligomeric $A \beta_{1-42}$ binds to TREM2 and activates TREM2 signaling pathway}

TREM2 deficiency was found to reduce the number of microglia clustering around $A \beta$ plaques $[21,25,26]$, suggesting a role of TREM2 in bridging the interaction between microglia and plaque. This prompts us to hypothesize that $A \beta$ aggregates serve as chemoattractant for microglia by binding to cell surface TREM2. To test this hypothesis, we used a soluble TREM2-Fc (sTREM2Fc) construct that consists of the extracellular domain of TREM2 spanning the N-terminal amino acids 1-171 fused to the Fc region of human IgG1 (Fig. 1a) as previously described [42]. The fusion protein was purified from the conditioned medium of transfected human embryonic kidney 293 T (HEK 293 T) cells (Fig. 1b). The extracellular domain of another TREM family member TREM1 fused to Fc (sTREM1-Fc) was also purified and served as a control (Fig. 1b). Soluble oA $\beta_{1-42}$ was assembled from synthetic $A \beta$ peptides as previously described [38, 39] and exhibited heterogeneous distribution as low- $n$ and high-n oligomers (Fig. 1c). In the solid phase protein binding assay, we found a specific binding of $\mathrm{oA} \beta_{1-42}$ to sTREM2-Fc with a $K_{\mathrm{D}}$ of $86.50 \mathrm{nM}$, but not to the Fc region alone or sTREM1-Fc (Fig. 1d). Furthermore, in vitro immunoprecipitation assay revealed that soluble oA $\beta_{1-42}$ species in the form of both low- $n$ and high-n aggregates were captured by bead-bound sTREM2-Fc but not sTREM1-Fc or Fc alone control (Fig. 1e), indicating a specific interaction between $A \beta$ oligomers and sTREM2. Consistent with the binding of synthetic $A \beta$ to TREM2, the endogenous $A \beta$ from the brain lysates of 5xFAD amyloid mice model also bound to TREM2 immobilized on beads (Additional file 1: Figure S1A). As a negative control, endogenous $A \beta$ was not detected when TREM1 was used as bait. Therefore, TREM2 specifically interacts with both synthetic and in vivo brain-derived $A \beta$. Co-localization between TREM2 and $\mathrm{oA} \beta_{1-42}$ on the cell surface was observed when HEK 293 T cells were transfected with TREM2-Cherry and incubated with FAM-oA $\beta_{1-42}$; whereas, co-localization was not observed between TERM1 and oA $\beta_{1-42}$ (Additional file 1: Figure $\mathrm{S} 1 \mathrm{~B}$ and Additional file 1: Figure $\mathrm{S} 1 \mathrm{C})$. The interaction between TREM2 and $\mathrm{oA} \beta_{1-42}$ was further confirmed by a surface plasmon resonance (SPR) assay which showed a dose-dependent binding of oA $\beta_{1-}$ ${ }_{42}$ to sTREM2-Fc fusion protein but not Fc alone (Fig. If and g). Since our oA $\beta_{1-42}$ was prepared without separation of monomeric $A \beta_{1-42}\left(\mathrm{~mA} \beta_{1-42}\right)$, we further tested whether $\mathrm{mA} \beta_{1-42}$ binds to TREM2. An SPR assay with 
$\mathbf{a}$

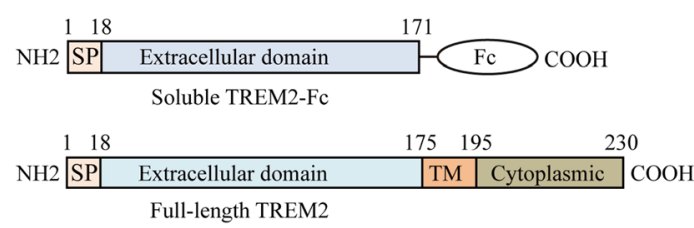

d

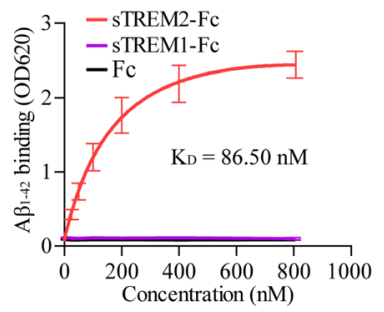

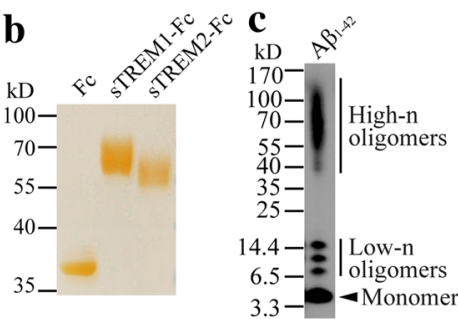

f

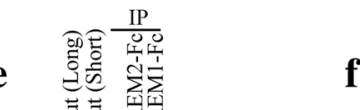

g
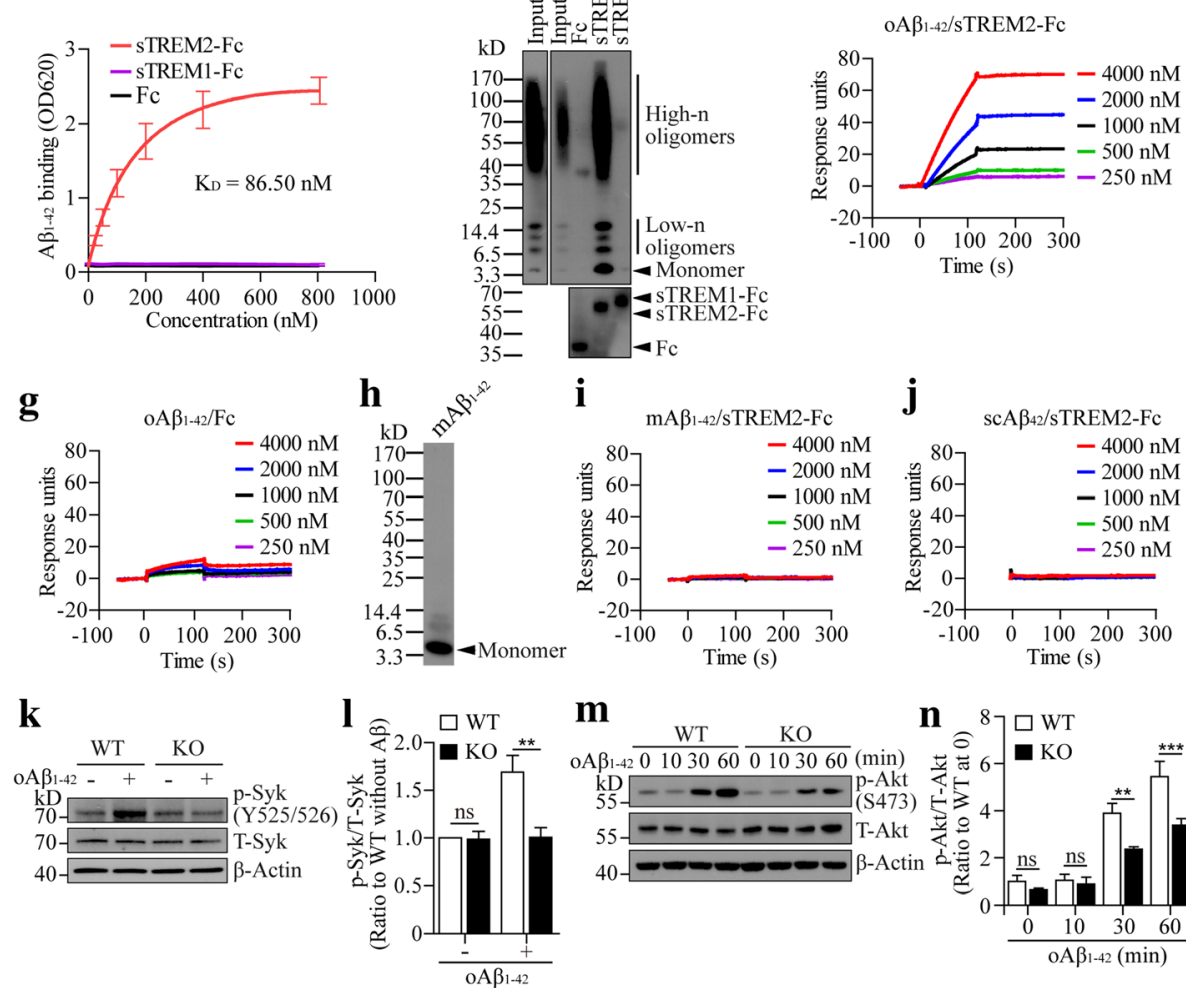

$\mathbf{m}$
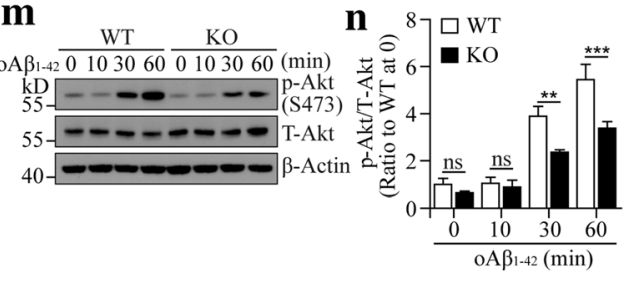

Fig. 1 Oligomeric $A \beta_{1-42}$ specifically binds to TREM2 and activates TREM2 signaling pathway. a Schematic representation of human TREM2 extracellular domain (sTREM2, amino acid residues 1-171) tagged with human IgG1 FC. SP: signal peptide. b The CDNA encoding sTREM2-FC, sTREM1-FC or FC alone was transfected into HEK 293 T cells. Each protein was purified from the conditioned medium and analyzed by silver stained SDS-PAGE. c The prepared $\mathrm{OA} \beta_{1-42}$ peptides were analyzed by Western blotting using 4-12\% Bis-Tris NuPAGE gel. $\mathbf{d}$ Solid phase binding assay showing the saturation binding curve and equilibrium dissociation constant $\left(K_{D}\right)$ of $O A \beta_{1-42}$ binding to sTREM2-Fc. Fc and sTREM1-Fc served as negative controls $(n=3)$. e The Fc, sTREM2-Fc or sTREM1-Fc control was pre-bound to protein A agarose beads and used as baits for immunoprecipitation of oA $\beta_{1-42}$. The precipitated products were separated on 4-12\% Bis-Tris NuPAGE gel and further subjected to Western blotting. ( $\mathbf{f}$ and $\mathbf{g}$ ) The binding profiles of oA $\beta_{1-42}$ to different concentrations of sTREM2-Fc $\mathbf{f}$ or FC $\mathbf{g}$ were generated by SPR assay. $\mathbf{h}$ The prepared monomeric $A \beta_{1-42}\left(\mathrm{~mA} \beta_{1-42}\right)$ peptides were analyzed by Western blotting using 4-12\% Bis-Tris NuPAGE gel. $\mathbf{i}$ The binding profiles of $m A \beta_{1-42}$ to different concentrations of sTREM2-Fc were generated by SPR assay. $\mathbf{j}$ The binding profiles of scrambled $A \beta_{42}\left(s c A \beta_{42}\right)$ to different concentrations of sTREM2-Fc were generated by SPR assay. $\mathbf{k}$ Wild-type (WT) or Trem2-knockout (KO) microglia were stimulated with $1.0 \mu \mathrm{M} \circ \mathrm{A} \beta_{1-42}$ for $1 \mathrm{~h}$. Cell lysates were analyzed by Western blotting using antibodies specific for either total (T-Syk) or phosphorylated form (p-Syk) of Syk. I Quantification of Western blots as ratios of p-Syk T-Syk. $\beta$-Actin was used as an internal control $(n=3$, two-way ANOVA). $\mathbf{m}$ WT or Trem2-KO microglia were stimulated with $1.0 \mu \mathrm{M} \circ \mathrm{A} \beta_{1-42}$ for the indicated time. Cell lysates at each time point were analyzed by Western blotting using antibodies specific for either total (T-Akt) or phosphorylated form (p-Akt) of Akt. $\mathbf{n}$ Quantification of Western blots as ratios of p-Akt/T-Akt. $\beta$-Actin was used as an internal control $\left(n=3\right.$, two-way ANOVA). Data information: Data represent mean \pm SD. ${ }^{* *}, p<0.01 ;{ }^{* *}, p<0.001$; ns, not significant

$\mathrm{mA} \beta_{1-42}$ was performed and showed that $\mathrm{mA} \beta_{1-42}$ had minimal binding to TREM2 (Fig. $1 \mathrm{~h}$ and i). The lack of interaction between scrambled $\mathrm{A} \beta_{42} \quad\left(\mathrm{scA} \beta_{42}\right)$ and sTREM2-Fc further confirmed the specific binding of oA $\beta_{1-42}$ to sTREM2-Fc (Fig. 1j). However, we did not include the characterization of fibrillar $A \beta$ in the binding assay due to its structural heterogeneity, limited solubility, and sticky nature. The binding efficiency of oA $\beta_{1-42}$ to STREM2-Fc was compared to that of the receptor for advanced glycosylation endproducts (RAGE), a 
microglial surface receptor that has been reported to induce microglial activation and chemotaxis upon binding to soluble $A \beta$ [43]. We found TREM2 showed a higher binding affinity for $\mathrm{oA} \beta_{1-42}$ than RAGE (Additional file 1: Figure S1D), supporting a potentially predominant role of TREM2 in mediating microglial-amyloid interaction. Taken together, our data revealed a specific interaction between TREM2 and $\mathrm{oA} \beta_{1-42}$, supporting $\mathrm{oA} \beta_{1-42}$ as a novel ligand for TREM2.

To determine if $\mathrm{oA} \beta_{1-42}$ can functionally engage TREM2 and initiate intracellular signaling, we utilized TREM2 reporter cells (TD4) which express both TREM2 and DAP12 and produce $\beta$-galactosidase upon TREM2 engagement [34]. As a positive control, ionomycin stimulated the expression of reporter $\beta$-galactosidase in both wild-type (WT) and TREM2 reporter cells (Additional file 1: Figure S2A and Additional file 1: Figure S2B). Consistent with $\mathrm{oA} \beta_{1-42}$ as a specific ligand for TREM2, it selectively activated TREM2 reporter cells but not WT cells in a dose-dependent manner, suggesting the requirement of TREM2 engagement. Consistent with the binding data, neither $\mathrm{mA} \beta_{1-42}$ nor scA $\beta_{42}$ stimulated the reporter activity in TD4 cells. To gain more direct evidence that oA $\beta_{1-42}$ stimulates TREM2 signaling, we compared the levels of phosphorylated Syk (p-Syk) and Akt (p-Akt) known to represent TREM2 activation in microglia [44]. The stimulation with $\mathrm{oA} \beta_{1-42}$ induced significantly higher level of p-Syk in WT but not Trem2-KO microglia (Fig. 1k and l). Furthermore, $\mathrm{oA} \beta_{1-42}$ increased to a greater extent of p-Akt in WT than Trem2-KO microglia at both the 30and 60-min time points (Fig. $1 \mathrm{~m}$ and $\mathrm{n}$ ). Taken together, these results indicate that $\mathrm{OA} \beta_{1-42}$ binds to TREM2 and activates TREM2-dependent signaling pathway in microglia. $\mathbf{a}$

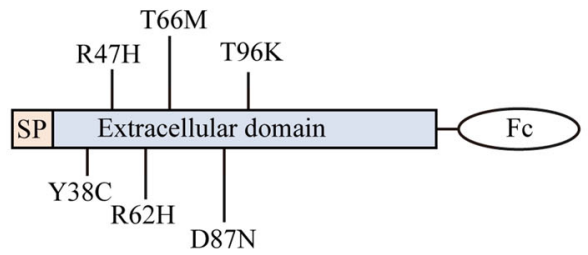

b

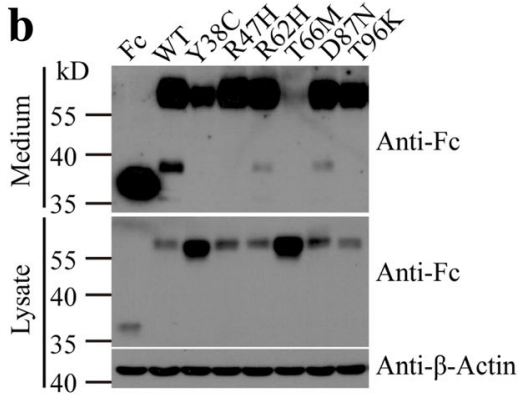

$\mathbf{e}$ c

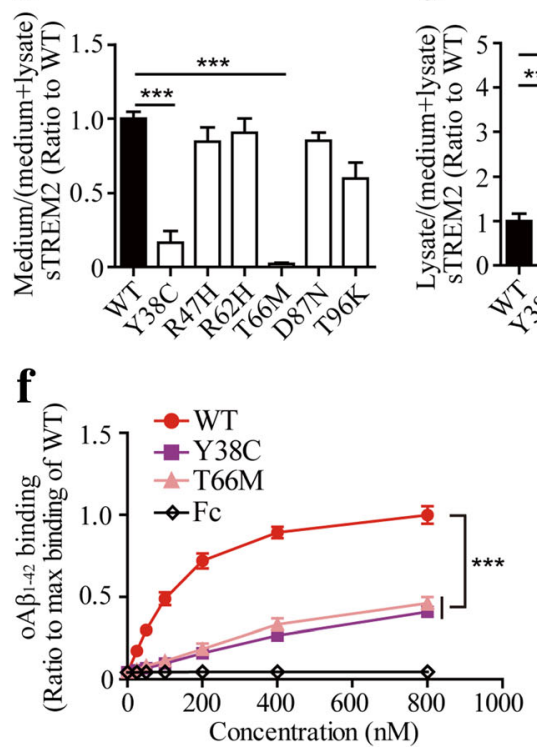

d

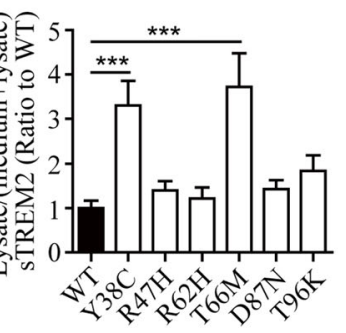

g

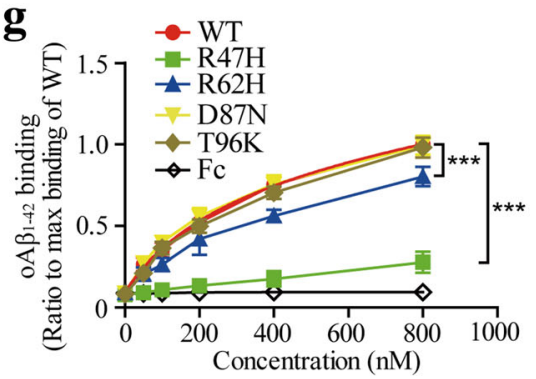

Fig. 2 The disease-associated mutations reduce TREM2 binding to $O A \beta_{1-42}$ a Schematic representation of NHD and AD-associated sTREM2 variants tagged with Fc. $\mathbf{b}$ Immunoblotting of sTREM2-Fc in the conditioned medium or cell lysate from HEK 293 T cells expressing AD-associated TREM2 mutations (R47H, R62H, D87N and T96 K) or NHD-associated TREM2 mutations (Y38C and T66 M). (c and d) Bar graphs show the quantification of Western blots from panel $B(n=3$, one-way ANOVA). e The purified Fc, wild-type sTREM2 WT-Fc (WT) and sTREM2-Fc with disease-associated mutations were analyzed by silver staining. ( $f$ and $\mathbf{g}$ ) Solid phase binding assay showing the binding affinity of $\circ A \beta_{1-42}$ to WT and different variants of TREM2-FC $\left(\mathrm{n}=3\right.$, two-way ANOVA). Data information: Data represent mean \pm SD. ${ }^{* *}, p<0.001$ 
The disease-associated mutations reduce TREM2 binding to $o A \beta_{1-42}$

The majority of disease-associated mutations are clustered within the putative ligand binding region of TREM2 ectodomain. With this in mind, we investigated how TREM2 variants affect its binding to oA $\beta_{1-42}$. We focused on two NHD-causing mutations (Y38C and T66 M) and four AD risk variants (R47H, R62H, D87N and T96 K) by generating sTREM2-Fc constructs carrying corresponding point mutations (Fig. 2a). Expression of Y38C and T66 M mutants in HEK 293 T cells resulted in a strong retention of sTREM2-Fc within the cytoplasm, thereby leading to reduced levels of both proteins in the conditioned medium (Figs. 2b-d). In contrast, none of the four AD risk-associated variants affected surface transport of sTREM2. Nevertheless, all proteins were purified to near homogeneity (Fig. 2e) and subjected to the solid phase protein binding assay using the same amount of each sTREM2-Fc variant. Compared to the wild-type (WT) protein, both NHD mutants exhibited dramatically decreased binding to oA $\beta_{1-42}$ (Fig. 2f). Among the four AD risk-associated variants, the $\mathrm{D} 87 \mathrm{~N}$ and $\mathrm{T} 96 \mathrm{~K}$ mutants bound to oA $\beta_{1-42}$ with comparable affinity to WT protein (Fig. 2g). However, the $\mathrm{R} 47 \mathrm{H}$ variant exhibited a large reduction (72\%) in binding to oA $\beta_{1-42}$; while the binding of $\mathrm{R} 62 \mathrm{H}$ mutant to oA $\beta_{1-42}$ was impaired to a lesser degree (20\%).

\section{Residues 31-91 of TREM2, in particular the positively} charged amino acids within this region, are crucial for its interaction with $\mathrm{oA} \beta_{1-42}$

In an attempt to map the critical region on TREM2 for its association with $\mathrm{oA} \beta_{1-42}$, we constructed a series of C-terminally truncated mutants of sTREM2-Fc (Fig. 3a). Expression of the mutants carrying residues 1-71 and 1-91 resulted in a significantly increased secretion of sTREM2 fragments into the medium (Figs. 3b-d). The truncation mutants were purified and subjected to $\mathrm{oA} \beta_{1-42}$ binding assay (Fig. 3e). Interestingly, mutants carrying residues $1-31$ showed no detectable binding to
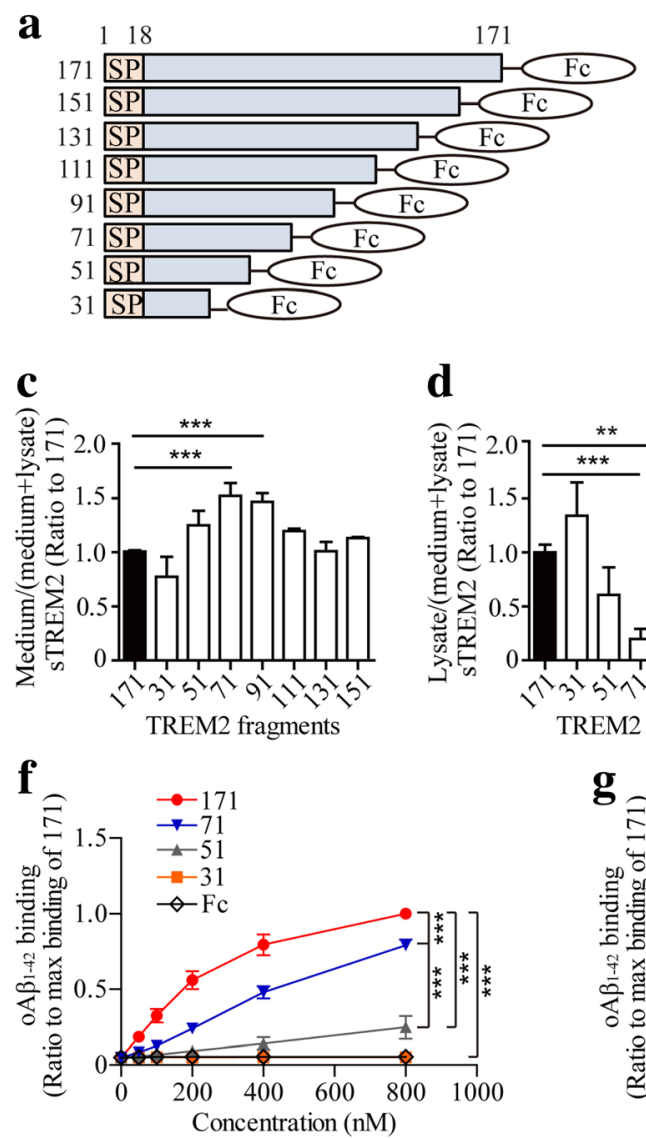

d
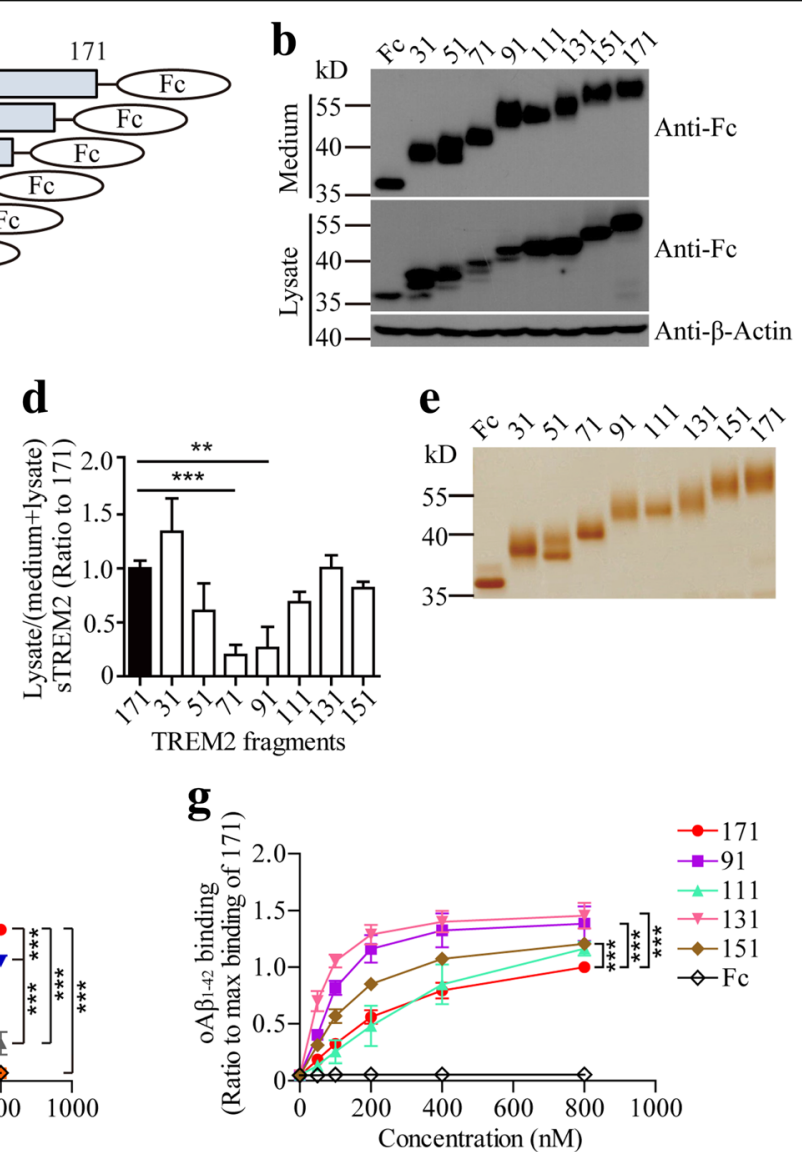

Fig. 3 Residues 31-91 of TREM2 are crucial for its interaction with $O A \beta_{1-42}$ a Schematic representation of different fragments of sTREM2-Fc. $\mathbf{b}$ Immunoblotting of sTREM2-Fc fragments in the conditioned medium or cell lysate from HEK 293 T cells. (c and d) Bar graphs showing the quantification of Western blots from panel B ( $n=3$, one-way ANOVA). e The purified Fc and sTREM2-Fc fragments were analyzed by silver staining. ( $\mathbf{f}$ and $\mathbf{g}$ ) Solid phase binding assay showing the binding affinity of $\mathrm{oA} \beta_{1-42}$ to sTREM2-FC fragments ( $\mathrm{n}=3$, two-way ANOVA). Data information: Data represent mean $\pm \mathrm{SD}$. ${ }^{* *}, p<0.01 ;{ }^{* * *}, p<0.001$ 
oA $\beta_{1-42}$, while both fragments spanning $1-51$ and $1-71$ residues exhibited a statistically significant reduction in binding to $\mathrm{oA} \beta_{1-42}$ as compared to the 1-171 fragment (Fig. 3f). For other truncation mutants, the binding affinity of the 1-111 fragment to $\mathrm{oA} \beta_{1-42}$ was similar to the 1-171 fragment. However, fragments carrying 1-91, 1-131 and 1-151 residues showed significantly higher affinity to $\mathrm{oA} \beta_{1-42}$ than the 1-171 fragment (Fig. 3g). Therefore, we conclude that residues $31-91$ of TREM2 are necessary for its interaction with $\mathrm{oA} \beta_{1-42}$.

Based on our observation that both $\mathrm{R} 47 \mathrm{H}$ and $\mathrm{R} 62 \mathrm{H}$ mutants significantly impaired the interaction between TREM2 and $\mathrm{oA} \beta_{1-42}$, we sought to examine whether the positively charged amino acids (arginine and lysine) within residues 31-91 play important roles in TREM2 binding to $\mathrm{oA} \beta_{1-42}$. Mutant forms of sTREM2-Fc carrying K42A, R46A, R47A, K48A, R52A, K57A, R62A, R76A or R77A mutation were constructed and expressed in HEK $293 \mathrm{~T}$ cells (Fig. 4a). The K42A, R47A, K57A, R62A, R76A and R77A mutants exhibited similar surface transport to WT sTREM2-Fc (Figs. 4b-d). However, the mutations in the forms of R46A, K48A or R52A led to significantly decreased levels of sTREM2 in the medium. Remarkably, the K48A mutation almost completely abolished the secretion of sTREM2 into the extracellular space, therefore preventing the follow-up protein purification for further analysis (Fig. 4e). Interestingly, all the mutations significantly reduced the binding affinity of TREM2 to oA $\beta_{1-42}$ (Fig. 4f), indicating that the interaction between TREM2 and $\mathrm{oA} \beta_{1-42}$ relies on the positively charged amino acids within residues 31-91of TREM2.

\section{Oligomeric $A \beta_{1-42}$ modulates microglial responses dependent on TREM2 receptor}

Both oA $\beta_{1-42}$ and TREM2 have been reported to modulate the migration of microglial cells $[45,46]$. We explored whether $\mathrm{oA} \beta_{1-42}$-induced cell migration in microglia relies on endogenous TREM2. Primary microglia were isolated from both WT and Trem2-knockout (KO) mice and subjected to the transwell migration assay in the presence or absence of oA $\beta_{1-42}$ (Figs. 5a and b). Consistent with previous reports, the deficiency of Trem 2 led to a significant
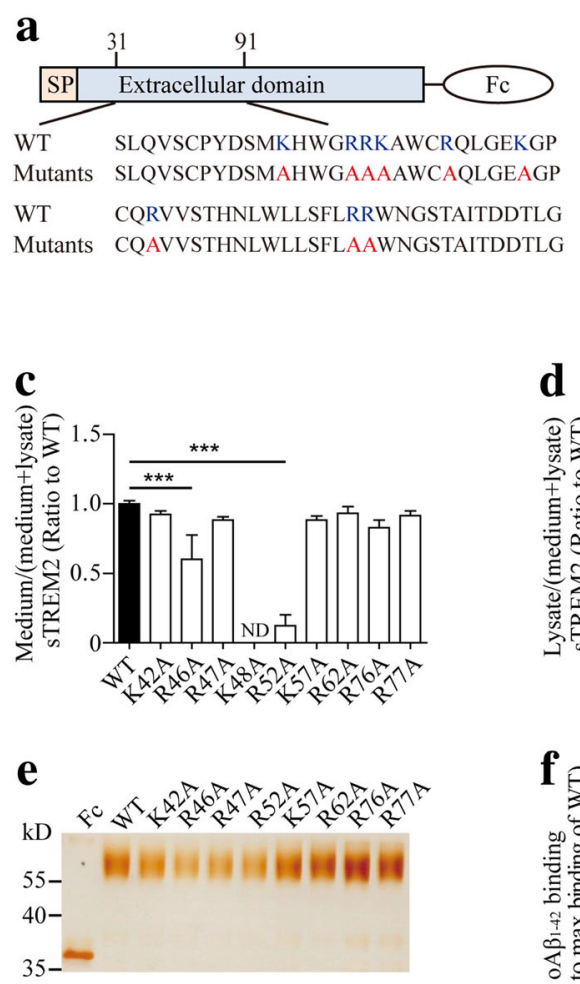

d
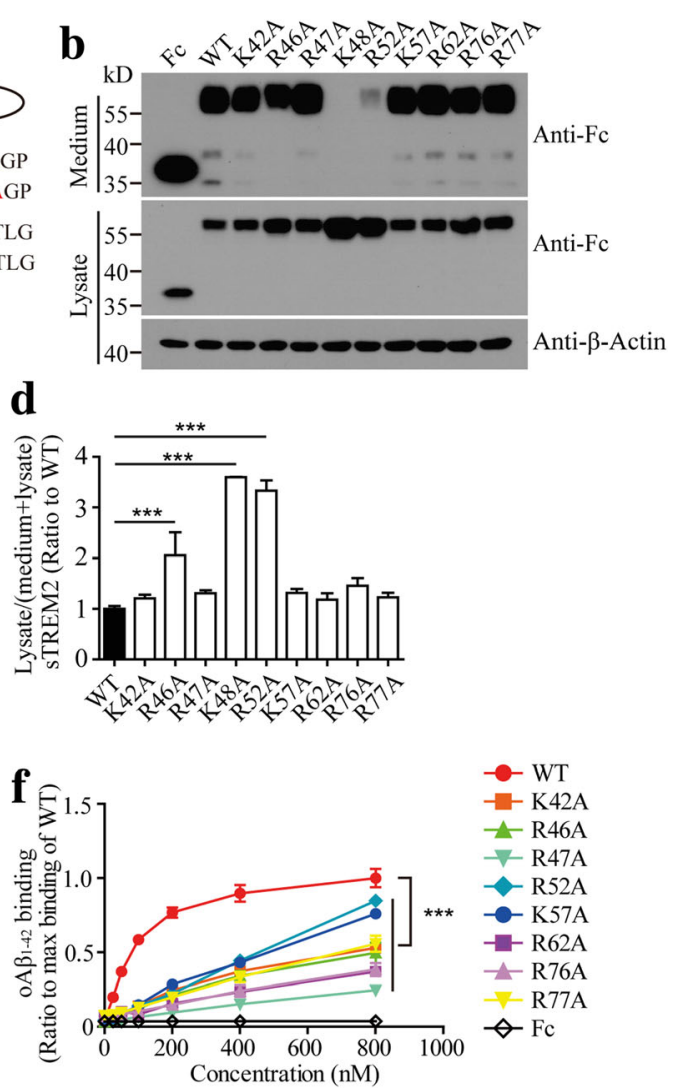

Fig. 4 The positively charged amino acids in TREM2 mediate its interaction with $O A \beta_{1-42}$. a Schematic representation of mutagenesis of positively charged amino acids on sTREM2-Fc. b Immunoblotting of sTREM2-Fc mutants in the conditioned medium or cell lysate from HEK $293 \mathrm{~T}$ cells. (c and $\mathbf{d})$ Bar graphs showing the quantification of Western blots from panel $B(n=3$, one-way ANOVA). ND: not determined. e The purified Fc and sTREM2-Fc mutants were analyzed by silver staining. $\mathbf{f}$ Solid phase binding assay showing the binding affinity of oA $\beta_{1-42}$ to sTREM2-FC mutants $\left(n=3\right.$, two-way ANOVA). Data information: Data represent mean \pm SD. ${ }^{* * *}, p<0.001$ 


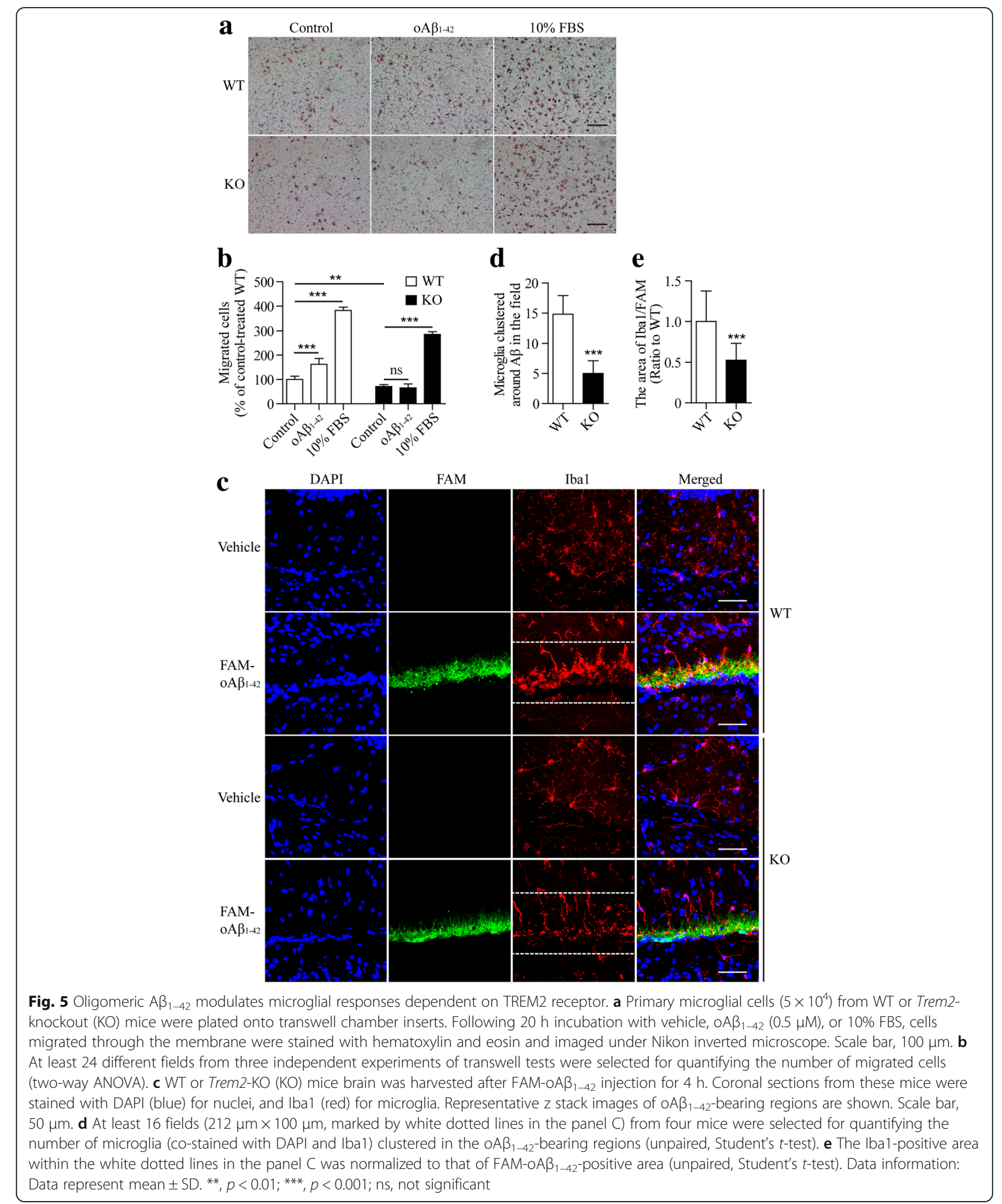

decrease in cell migration across the transwell membrane [45]. Treatment with oA $\beta_{1-42}$ aggregates caused an increase in the migration of WT microglia as compared to the vehicle control. In contrast, $\mathrm{oA} \beta_{1-42}$ was incapable of inducing migration of Trem2-KO microglial cells. Notably, the 10\% FBS (Fig. 5a and b) and ATP (Additional file 1: 
Figure S3A and Additional file 1: Figure S3B) dramatically stimulated the migration of both WT and Trem2-KO microglial cells, suggesting that the lack of response to $\mathrm{oA} \beta_{1-42}$ in Trem2-KO microglia is likely specific. To further test whether TREM2 modulates the clustering of microglia around $\mathrm{oA} \beta_{1-42}$ aggregates in vivo, we stereotactically injected FAM-oA $\beta_{1-42}$ into the hippocampi of adult WT and Trem2-KO mice and quantified the number of microglia in the vicinity of $\mathrm{oA} \beta_{1-42}$. A significantly increased number of microglia accumulated around the injected $\mathrm{A} \beta$ in WT mouse brain as early as $4 \mathrm{~h}$ postinjection; however, the effect was diminished in the absence of Trem2 (Figs. 5c-e). Similar results were obtained $16 \mathrm{~h}$ postinjection (Additional file 1: Figure S3C, Additional file 1: Figure S3D and Additional file 1: Figure S3E), further supporting a key role of TREM2 in microglial clustering around amyloid in vivo. Taken together, our data revealed that $\mathrm{oA} \beta_{1-42}$ promotes microglial migration in vitro and clustering in vivo in a TREM2-dependent manner.

\section{Discussion}

Human genetic association studies increasingly highlight microglial genes, such as TREM2, CD33, and CR1 playing important roles in the pathogenesis of AD [47]. Although mechanistic understanding of TREM2 action remains elusive, TREM2 presumably carries out its function in $\mathrm{AD}$ by binding to endogenous ligand(s). The many diverse ligands reported for TREM2 suggest that TREM2 is a highly promiscuous receptor. In this study, we found that oA $\beta$ specifically bound to TREM2 with high affinity. The interaction is functionally relevant to the pathogenesis of $\mathrm{AD}$ as evidenced by the observation that $\mathrm{oA} \beta$ triggers microglial migration in vitro and microglial clustering around $\mathrm{oA} \beta$-bearing regions in vivo in a TREM2-dependent manner. Therefore, different ligands of TREM2 likely trigger ligand-specific events to accomplish the multifunctions reported for TREM2, in the case of oA $\beta$ microglial migration.

Interestingly, the disease-associated mutations of TREM2 reduced its binding affinity to $A \beta$. Although coding variants of TREM2 are linked to the risk of neurodegenerative diseases, the underlying mechanisms remain unknown. Several recent studies have shed light on how TREM2 missense mutations affect TREM2 function. First, the disease-associated mutations of TREM2 have impaired cell surface expression as reported previously $[48,49]$ and in our current study. Second, TREM2 missense mutations have been reported to reduce its shedding by ADAM proteases and impair the phagocytic activity of TREM2-expressing cells [48]. Furthermore, AD risk-associated mutations abrogate the function of soluble TREM2 in both suppressing apoptosis and triggering inflammatory responses [42]. Importantly, TREM2 variants exhibited deficits in binding to a wide array of ligands, including phospholipids, apolipoproteins, lipoprotein particles [21, 35-37] and $\mathrm{oA} \beta_{1-42}$ as reported in the current study. Taken together, the disease-associated mutations of TREM2 likely modify the disease progression via multiple pathways.

Although our current study emphasizes a critical role of membrane-bound TREM2 which associates with DAP12 for downstream signaling, we could not rule out a potential contribution by sTREM2, a shed product of membrane-bound TREM2, that binds to a yet identified microglial receptor [42]. Hence, both full-length TREM2 and STREM2 might be involved in microglial recruitment to the vicinity of plaques. Although the molecular mechanism underlying each pathway remains to be defined in future, our data suggest that the membranebound TREM2 signals through Syk and Akt, while sTREM2 might act on a separate microglial cell-surface receptor [42].

One striking feature of microglia in AD brain is their universal clustering around amyloid plaque. It was consistently reported that the number of microglia around amyloid plaques was reduced in Trem2-deficient amyloid mouse models, leading to an increase in less compact plaques [26, 28]. A critical function of microglia is thought to remove $A \beta$ deposits via phagocytosis [50]. Indeed, loss of Trem 2 has been reported to impair the phagocytosis of $A \beta$ by microglia in vitro [48]. Therefore, the physical interaction between TREM2 and A $\beta$ likely regulates microglial mobility, potentially contributing to both the barrier function of microglia to compact the plaques and the phagocytic activity of microglia in removing the plaques. Future studies elucidating the biological function of their interaction might uncover targetable pathways for AD therapy.

\section{Conclusions}

Our current study demonstrates that oA $\beta$ binds to TREM2 with high affinity and activates TREM2-dependent signaling pathways in microglia. The absence of TREM2 impairs the oA $\beta$-induced microglial migration in vitro and microglial clustering around $\mathrm{OA} \beta$-bearing brain regions in vivo. The identification of $\mathrm{A} \beta$ as a novel TREM2 ligand links TREM2 to the most prominent pathological features of $A D$ and provides a critical mechanism by which microglia recognize and react to $A \beta$ pathology.

\section{Additional file}

Additional file 1: Figure S1. Oligomeric $A \beta_{1-42}$ specifically binds to TREM2. Figure $\mathbf{S} 2$. Oligomeric $A \beta_{1-42}$ specifically activates TREM2 reporter cells. Figure S3. The number of microglia clustered around $A \beta$ is decreased in Trem2-KO mice. (PDF 1369 kb) 


\section{Abbreviations}

AD: Alzheimer's Disease; CNS: Central Nervous System; DAP12: DNAXactivating Protein of 12 kDa; GM-CSF: Granulocyte-Macrophage Colonystimulating Factor; OA $\beta_{1-42}$ : Oligomeric Amyloid- $\beta$ 1-42; RAGE: Receptor for Advanced Glycosylation Endproducts; SPR: Surface Plasmon Resonance; STREM2: soluble TREM2; TREM1: Triggering Receptor expressed on Myeloid Cells 1; TREM2: Triggering Receptor expressed on Myeloid Cells 2

\section{Acknowledgements}

The authors thank Junjie Chen from the Analysis and Measurement Center, School of Pharmaceutical Sciences, Xiamen University for kindly performing the data analysis on surface plasmon resonance assay.

\section{Author contributions}

X.C., G.B., L.Z., Z.W. and H.X. designed research; L.Z., Z.W., D.W., Z.W., Y.M., L.W., K.W., Y.X., J.L., R.H. and D.C. performed experiments; L.Z., Z.W., D.W., Z.W., Y.M. and X.C. analyzed data; X.C., Z.W. L.Z. and G.B. wrote the manuscript. All authors read and approved the final manuscript.

\section{Funding}

Research by the authors was supported by a grant from the Natural Science Foundation of Guangdong Province 2016A030306005 (to X.C.), grants from the National Natural Science Foundation of China 81370459, 31400914 (to X.C.), U1505227 (to G.B.), U1405222, 81771163 (to H.X.), 81701079 (to L.Z.), a grant from the Fundamental Research Funds for the Central Universities (20720180055, to X.C.), NIH grants RF1AG056130 (to G.B. and H.X.), R01AG035355 (to G.B.), R37AG027924 (to G.B.), RF1AG056114 (to H.X.); grants from the Postdoctoral Science Foundation of China 2016 M600503 and 2017 T100469 (to L.Z.), and the Cure Alzheimer's Fund (to G.B. and H.X.).

\section{Availability of data and materials}

Not applicable.

\section{Ethics approval and consent to participate}

All animal experiments were conducted in compliance with the protocols of the Institutional Animal Care and Use Committee at Xiamen University.

\section{Consent for publication}

Not applicable.

\section{Competing interests}

The authors declare that they have no competing interests.

\section{Publisher's Note}

Springer Nature remains neutral with regard to jurisdictional claims in published maps and institutional affiliations.

\section{Author details}

${ }^{1}$ Fujian Provincial Key Laboratory of Neurodegenerative Disease and Aging Research, Institute of Neuroscience, Medical College, Xiamen University, Xiamen 361102, China. ²Department of Neuroscience, Mayo Clinic, Jacksonville, FL 32224, USA. ${ }^{3}$ Neuroscience Initiative, Sanford Burnham Prebys Medical Discovery Institute, La Jolla, CA 92037, USA. ${ }^{4}$ Shenzhen Research Institute of Xiamen University, Shenzhen 518063, China.

Received: 15 March 2018 Accepted: 20 March 2018 Published online: 27 March 2018

\section{References}

1. Holtzman DM, Morris JC, Goate AM. Alzheimer's disease: the challenge of the second century. Sci Transl Med. 2011;3:77-1.

2. Huang Y, Mucke L. Alzheimer mechanisms and therapeutic strategies. Cell. 2012:148:1204-22.

3. Mandrekar S, Jiang Q, Lee CY, Koenigsknecht-Talboo J, Holtzman DM, Landreth GE. Microglia mediate the clearance of soluble Abeta through fluid phase macropinocytosis. J Neurosci. 2009;29:4252-62.

4. El Khoury J, Toft M, Hickman SE, Means TK, Terada K, Geula C, Luster AD. Ccr2 deficiency impairs microglial accumulation and accelerates progression of Alzheimer-like disease. Nat Med. 2007;13:432-8.

5. Hanisch UK, Kettenmann H. Microglia: active sensor and versatile effector cells in the normal and pathologic brain. Nat Neurosci. 2007;10:1387-94.
6. Condello C, Yuan P, Schain A, Grutzendler J. Microglia constitute a barrier that prevents neurotoxic protofibrillar Abeta42 hotspots around plaques. Nat Commun. 2015;6:6176

7. Zhao R, Hu W, Tsai J, Li W, Gan WB. Microglia limit the expansion of betaamyloid plaques in a mouse model of Alzheimer's disease. Mol Neurodegener. 2017;12:47.

8. Guerreiro R, Wojtas A, Bras J, Carrasquillo M, Rogaeva E, Majounie E, Cruchaga C, Sassi C, Kauwe JS, Younkin S, et al. TREM2 variants in Alzheimer's disease. N Engl J Med. 2013;368:117-27.

9. Jonsson $T$, Stefansson $H$, Steinberg $S$, Jonsdottir I, Jonsson PV, Snaedal J, Bjornsson S, Huttenlocher J, Levey Al, Lah JJ, et al. Variant of TREM2 associated with the risk of Alzheimer's disease. N Engl J Med. 2013;368:107-16.

10. Jin SC, Benitez BA, Karch CM, Cooper B, Skorupa T, Carrell D, Norton JB, Hsu $\mathrm{S}$, Harari $\mathrm{O}$, Cai $Y$, et al. Coding variants in TREM2 increase risk for Alzheimer's disease. Hum Mol Genet. 2014;23:5838-46.

11. Korvatska O, Leverenz JB, Jayadev S, McMillan P, Kurtz I, Guo X, Rumbaugh M, Matsushita M, Girirajan S, Dorschner MO, et al. R47H Variant of TREM2 Associated With Alzheimer Disease in a Large Late-Onset Family: Clinical, Genetic, and Neuropathological Study. JAMA Neurol. 2015;72:920-7.

12. Bertram L, Lange C, Mullin K, Parkinson M, Hsiao M, Hogan MF, Schjeide BM, Hooli B, Divito J, Ionita I, et al. Genome-wide association analysis reveals putative Alzheimer's disease susceptibility loci in addition to APOE. Am J Hum Genet. 2008;83:623-32.

13. Naj AC, Jun G, Beecham GW, Wang LS, Vardarajan BN, Buros J, Gallins PJ, Buxbaum JD, Jarvik GP, Crane PK, et al. Common variants at MS4A4/ MS4A6E, CD2AP, CD33 and EPHA1 are associated with late-onset Alzheimer's disease. Nat Genet. 2011;43:436-41.

14. Hollingworth P, Harold D, Sims R, Gerrish A, Lambert JC, Carrasquillo MM, Abraham R, Hamshere ML, Pahwa JS, Moskvina V, et al. Common variants at ABCA7, MS4A6A/MS4A4E, EPHA1, CD33 and CD2AP are associated with Alzheimer's disease. Nat Genet. 2011;43:429-35.

15. Huang KL, Marcora E, Pimenova AA, Di Narzo AF, Kapoor M, Jin SC, Harari O, Bertelsen S, Fairfax BP, Czajkowski J, et al. A common haplotype lowers PU.1 expression in myeloid cells and delays onset of Alzheimer's disease. Nat Neurosci. 2017;20:1052-61.

16. Keren-Shaul H, Spinrad A, Weiner A, Matcovitch-Natan O, Dvir-Szternfeld R, Ulland TK, David E, Baruch K, Lara-Astaiso D, Toth B, et al. A Unique Microglia Type Associated with Restricting Development of Alzheimer's Disease. Cell. 2017;169:1276-90. e1217

17. Schmid CD, Sautkulis LN, Danielson PE, Cooper J, Hasel KW, Hilbush BS, Sutcliffe JG, Carson MJ. Heterogeneous expression of the triggering receptor expressed on myeloid cells-2 on adult murine microglia. J Neurochem. 2002;83:1309-20.

18. Jay TR, von Saucken VE, Landreth GE. TREM2 in Neurodegenerative Diseases. Mol Neurodegener. 2017;12:56

19. Guerreiro R, Hardy J. TREM2 and neurodegenerative disease. N Engl J Med. 2013:369:1569-70

20. Jin SC, Carrasquillo MM, Benitez BA, Skorupa T, Carrell D, Patel D, Lincoln S, Krishnan S, Kachadoorian M, Reitz C, et al. TREM2 is associated with increased risk for Alzheimer's disease in African Americans. Mol Neurodegener. 2015;10:19.

21. Wang Y, Cella M, Mallinson K, Ulrich JD, Young KL, Robinette ML, Gilfillan S, Krishnan GM, Sudhakar S, Zinselmeyer BH, et al. TREM2 lipid sensing sustains the microglial response in an Alzheimer's disease model. Cell. 2015;160:1061-71.

22. Zheng $H$, Jia L, Liu CC, Rong Z, Zhong L, Yang L, Chen XF, Fryer JD, Wang $X$, Zhang YW, et al. TREM2 Promotes Microglial Survival by Activating Wnt/ beta-Catenin Pathway. J Neurosci. 2017;37:1772-84.

23. Takahashi K, Rochford CD, Neumann $\mathrm{H}$. Clearance of apoptotic neurons without inflammation by microglial triggering receptor expressed on myeloid cells-2. J Exp Med. 2005;201:647-57.

24. Zhong L, Chen XF, Zhang ZL, Wang Z, Shi XZ, Xu K, Zhang YW, Xu H, Bu G. DAP12 Stabilizes the C-terminal Fragment of the Triggering Receptor Expressed on Myeloid Cells-2 (TREM2) and Protects against LPS-induced Pro-inflammatory Response. J Biol Chem. 2015;290:15866-77.

25. Jay TR, Miller CM, Cheng PJ, Graham LC, Bemiller S, Broihier ML, Xu G, Margevicius D, Karlo JC, Sousa GL, et al. TREM2 deficiency eliminates TREM2 + inflammatory macrophages and ameliorates pathology in Alzheimer's disease mouse models. J Exp Med. 2015;212:287-95.

26. Wang Y, Ulland TK, Ulrich JD, Song W, Tzaferis JA, Hole JT, Yuan P, Mahan TE, Shi Y, Gilfillan $S$, et al. TREM2-mediated early microglial response limits diffusion and toxicity of amyloid plaques. J Exp Med. 2016;213:667-75. 
27. Jay TR, Hirsch AM, Broihier ML, Miller CM, Neilson LE, Ransohoff RM, Lamb BT, Landreth GE. Disease Progression-Dependent Effects of TREM2 Deficiency in a Mouse Model of Alzheimer's Disease. J Neurosci. 2017;37: 637-47.

28. Yuan P, Condello C, Keene CD, Wang Y, Bird TD, Paul SM, Luo W, Colonna M, Baddeley D, Grutzendler J. TREM2 Haplodeficiency in Mice and Humans Impairs the Microglia Barrier Function Leading to Decreased Amyloid Compaction and Severe Axonal Dystrophy. Neuron. 2016;92:252-64.

29. Kober DL, Brett TJ. TREM2-Ligand Interactions in Health and Disease. J Mol Biol. 2017:429:1607-29.

30. Daws MR, Sullam PM, Niemi EC, Chen TT, Tchao NK, Seaman WE. Pattern recognition by TREM-2: binding of anionic ligands. J Immunol. 2003;171: 594-9.

31. Quan DN, Cooper MD, Potter JL, Roberts MH, Cheng H, Jarvis GA. TREM-2 binds to lipooligosaccharides of Neisseria gonorrhoeae and is expressed on reproductive tract epithelial cells. Mucosal Immunol. 2008;1:229-38.

32. Hamerman JA, Jarjoura JR, Humphrey MB, Nakamura MC, Seaman WE, Lanier LL. Cutting edge: inhibition of TLR and FCR responses in macrophages by triggering receptor expressed on myeloid cells (TREM)-2 and DAP12. J Immunol. 2006;177:2051-5.

33. Stefano L, Racchetti G, Bianco F, Passini N, Gupta RS, Bordignon PP, Meldolesi J. The surface-exposed chaperone, Hsp60, is an agonist of the microglial TREM2 receptor. J Neurochem. 2009;110:284-94.

34. Hsieh CL, Koike M, Spusta SC, Niemi EC, Yenari M, Nakamura MC, Seaman WE. A role for TREM2 ligands in the phagocytosis of apoptotic neuronal cells by microglia. J Neurochem. 2009;109:1144-56.

35. Atagi Y, Liu CC, Painter MM, Chen XF, Verbeeck C, Zheng H, Li X, Rademakers R, Kang SS, Xu H, et al. Apolipoprotein E Is a Ligand for Triggering Receptor Expressed on Myeloid Cells 2 (TREM2). J Biol Chem. 2015;290:26043-50.

36. Bailey CC, DeVaux LB, Farzan M. The Triggering Receptor Expressed on Myeloid Cells 2 Binds Apolipoprotein E. J Biol Chem. 2015;290:26033-42.

37. Yeh FL, Wang Y, Tom I, Gonzalez LC, Sheng M. TREM2 Binds to Apolipoproteins, Including APOE and CLU/APOJ, and Thereby Facilitates Uptake of Amyloid-Beta by Microglia. Neuron. 2016;91:328-40.

38. Stine WB Jr, Dahlgren KN, Krafft GA, LaDu MJ. In vitro characterization of conditions for amyloid-beta peptide oligomerization and fibrillogenesis. J Biol Chem. 2003;278:11612-22.

39. Kim T, Vidal GS, Djurisic M, William CM, Birnbaum ME, Garcia KC, Hyman BT, Shatz CJ. Human LilrB2 is a beta-amyloid receptor and its murine homolog PirB regulates synaptic plasticity in an Alzheimer's model. Science. 2013;341: 1399-404.

40. Zhu X, Wang S, Yu L, Yang H, Tan R, Yin K, Jin J, Zhao H, Guan D, Xu Y. TL-2 attenuates beta-amyloid induced neuronal apoptosis through the AKT/GSK3beta/beta-catenin pathway. Int J Neuropsychopharmacol. 2014;17:1511-9.

41. Sanderson S, Shastri N. LacZ inducible, antigen/MHC-specific T cell hybrids. Int Immunol. 1994;6:369-76.

42. Zhong L, Chen XF, Wang T, Wang Z, Liao C, Wang Z, Huang R, Wang D, Li $X, W u L$, et al. Soluble TREM2 induces inflammatory responses and enhances microglial survival. J Exp Med. 2017;214:597-607.

43. Yan SD, Chen X, Fu J, Chen M, Zhu H, Roher A, Slattery T, Zhao L, Nagashima M, Morser J, et al. RAGE and amyloid-beta peptide neurotoxicity in Alzheimer's disease. Nature. 1996;382:685-91.

44. Peng Q, Malhotra S, Torchia JA, Kerr WG, Coggeshall KM, Humphrey MB. TREM2- and DAP12-dependent activation of PI3K requires DAP10 and is inhibited by SHIP1. Sci Signal. 2010;3:ra38.

45. Mazaheri F, Snaidero N, Kleinberger G, Madore C, Daria A, Werner G, Krasemann S, Capell A, Trumbach D, Wurst W, et al. TREM2 deficiency impairs chemotaxis and microglial responses to neuronal injury. EMBO Rep. 2017;18:1186-98.

46. Kim HJ, Ajit D, Peterson TS, Wang Y, Camden JM, Gibson Wood W, Sun GY, Erb L, Petris $M$, Weisman GA. Nucleotides released from $A \beta_{1-42}$-treated microglial cells increase cell migration and $A \beta_{1-42}$ uptake through $P 2 Y_{2}$ receptor activation. J Neurochem. 2012;121:228-38.

47. Malik M, Parikh I, Vasquez JB, Smith C, Tai L, Bu G, MJ LD, Fardo DW, Rebeck GW, Estus S. Genetics ignite focus on microglial inflammation in Alzheimer's disease. Mol Neurodegener. 2015;10:52

48. Kleinberger $G$, Yamanishi $Y$, Suarez-Calvet M, Czirr E, Lohmann E, Cuyvers $E$, Struyfs $\mathrm{H}$, Pettkus N, Wenninger-Weinzierl A, Mazaheri F, et al. TREM2 mutations implicated in neurodegeneration impair cell surface transport and phagocytosis. Sci Transl Med. 2014;6:243-86.
49. Sirkis DW, Bonham LW, Aparicio RE, Geier EG, Ramos EM, Wang Q, Karydas A, Miller ZA, Miller BL, Coppola G, Yokoyama JS. Rare TREM2 variants associated with Alzheimer's disease display reduced cell surface expression. Acta Neuropathol Commun. 2016;4:98.

50. Lee CY, Landreth GE. The role of microglia in amyloid clearance from the AD brain. J Neural Transm (Vienna). 2010;117:949-60.

\section{Submit your next manuscript to BioMed Central and we will help you at every step:}

- We accept pre-submission inquiries

- Our selector tool helps you to find the most relevant journal

- We provide round the clock customer support

- Convenient online submission

- Thorough peer review

- Inclusion in PubMed and all major indexing services

- Maximum visibility for your research

Submit your manuscript at www.biomedcentral.com/submit
Biomed Central 